
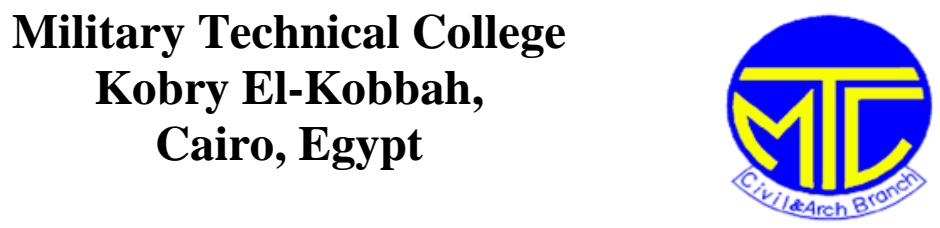

\title{
Rheological Properties of Fly Ash Self-consolidated Concrete
}

\author{
Eng. A. Kh. EL-Baz ${ }^{1}$, Khaled M. Heiza ${ }^{2}$, Omar A. El Nawawy ${ }^{3}$ \\ ${ }^{1}$ Eng, Future University, Cairo, Egypt \\ Email: abdelrahmankhelbaz@yahoo.com \\ ${ }^{2}$ Professor of RC Structures, Vice Dean, Faculty of Engineering, Menofia University, Egypt. \\ ${ }^{3}$ Professor of RC Structures, Faculty of Engineering, Menofia University, Egypt.
}

\begin{abstract}
The production of Self- consolidated concrete (SCC) is a relatively new technology. Nowadays, the production of SCC is becoming more popular in all over the world due to its superior properties. Self-compacting concrete is a fluid mixture suitable for placing in structures with congested reinforcement without vibration. Self- consolidated concrete development must ensure a good balance between deformability and stability. Also, compactibility is affected by the characteristics of materials and the mix proportions, it becomes necessary to evolve a procedure for mix design of SCC. The paper presents an experimental procedure for the design of self-compacting concrete mixes with different water/binder ratio and the effect of mineral admixtures -fly ash or silica fume- on fresh and hardened properties of SCC. The test results for acceptance characteristics of self-compacting concrete such as slump flow, J-ring and V-funnel are presented. Further, compressive strength at 7 and 28 days was also determined and results are analyzed and discussed.
\end{abstract}

Keywords: self-compacting concrete, fly ash, mix design, rheological properties, hardened concrete properties, compressive Strength.

\section{1- INTRODUCTION}

The production of SCC is becoming more popular owing to its superior properties. However, the production of SCC requires more sensitive and efficient workmanship and equipment. In addition to many other factors, such as proportioning and curing, the origin of coarse aggregate and mineral admixtures carries most importance in terms of rheological and mechanical properties of SCC. The highly flowable nature of SCC is due to very careful mix proportioning, usually replacing much of the coarse aggregate with fines and cement, and adding chemical admixtures [1]. Self-compacting concrete have high workability, low water cement ratio, and have high compressive strength at early ages [2]. Selçuk Türkel and Ali Kandemir study the effect of two mineral admixtures fly ash (FA) and limestone powder (LP) and two types of coarse aggregates limestone and olivine basalt on fresh and hardened (SCC). Results showed that the effect of mineral admixtures on fresh properties seems to be more dominant than the effect of aggregate type. Limestone powder and limestone aggregate combinations had superior fresh and mechanical properties compared to basalt-incorporated mixtures. The 28-day compressive strength of SCC made with limestone aggregates and FA combinations are about 15 to 27\% higher when compared to the other combinations of SCC [3]. (Fang and Teng) [4] made three mixes of SCC and noted that the use of mineral 
admixtures (e.g. silica fume and fly ash) may influence the behavior of FRP-confined concrete. Felekoglu et al. [5] made five mixes with different percent of super plasticizers, and different water quantities ranging between (140-227) liter $/ \mathrm{m}^{3}$ to get a proper method of mix design for SCC. They concluded that a proper fresh SCC property can be obtained if the mixing time does not exceed 30 minutes and the casting is not later than 30 minutes after mixing. Paratibha Aggarwal showed that at the water/powder ratio of 1.180 to 1.215 , slump flow test, V-funnel test and L-box test results were found to be satisfactory, i.e. passing ability, filling ability and segregation resistance are well within the limits [6]. Krishna and Reddy M. present an experimental procedure for the design of self-compacting concrete mixes by A simple tools with $29 \%$ of coarse aggregate, replacement of cement with Metakaolin and class F fly ash [7].

\section{2- MATERIAL PROPERTIES}

\section{CEMENT}

Ordinary Portland cement (Grade 42.5) was used is all SCC mixes. That satisfies the requirements of the Egyptian Standard Specification ESS 4756-1[8]. The specific gravity of cement is 3.15 .

\section{CHEMICAL ADMIXTURES}

Sika ViscoCrete ${ }^{\circledR}-5930$ is a third generation super plasticizer for concrete and mortar was used . It meets the requirements for super plasticizer according to ASTM-C- 494 Types G and $\mathrm{F}$ and BS EN 934 part 2: 2001. It produces high flowability of the mix while preserving its viscosity.

\section{ADDITIVE OR MINERAL ADMIXTURE}

Fly ash powder (Pozzocrete 60) is added to the normal strength concrete mix as a filler material in order to achieve the needed paste volume to produce self-compacting concrete. Fly ash obtained from "gitanjali colony, India nagar. The physical properties of fly ash are given in the (Table 1). It confirms to IS 3812 - part 1 fly ash.

Table (1) Physical Properties of Fly Ash

\begin{tabular}{|l|l|}
\hline Physical Properties & Test Results \\
\hline Colour & Light Grey \\
\hline Specific Gravity & 2.3 \\
\hline
\end{tabular}

Silica fume (Sika Fume ${ }^{\circledR}$-HR). The silica has a specific weight of 2.10. Sika Fume ${ }^{\circledR}$-HR is a concrete additive of a new generation in powder form, based on Sika silicafume ${ }^{\circledR}$ technology.

\section{COARSE AGGREGATE}

The coarse aggregate is size no 1 crushed dolomite, i.e. a maximum nominal size of $10 \mathrm{~mm}$. Its specific weight equals 2.50 and the percentage of absorption equals $1.2 \%$.

\section{FINE AGGREGATE}

The fine aggregate used in the concrete mixes is siliceous sand with a specific weight of 2.65 and percentage of absorption of $0.40 \%$

\section{WATER}

Ordinary tap water is used

\section{3- TEST METHODS}

Self- Compacting Concrete is characterized by filling ability, passing ability and resistance to segregation. Many different methods have been developed to characterize the properties of SCC. No single method has been found until date, which characterizes all the relevant 
workability aspects, and hence, each mix has been tested by more than one test method for the different workability parameters. (Table 2) gives the recommended values for different rheological tests according to the Egyptian Technical Specifications for Self Compacting Concrete[9].

Table (2) Recommended Limits for Different Rheological Tests For SCC Mixes

\begin{tabular}{|l|l|l|}
\hline Sr. No. & Property & Range \\
\hline $\mathbf{1 .}$ & Slump Flow Diameter & $600-800 \mathrm{~mm}$ \\
\hline $\mathbf{2 .}$ & T50cm & $2-5 \mathrm{sec}$ \\
\hline $\mathbf{3 .}$ & V-funnel ( T0sec) & $6-12 \mathrm{sec}$ \\
\hline $\mathbf{4 .}$ & V-funnel ( T5min) & $6-15 \mathrm{sec}$ \\
\hline $\mathbf{5 .}$ & J ring $(\Delta \mathrm{H})$ & $0-20 \mathrm{~mm}$ \\
\hline $\mathbf{6 .}$ & J ring T50cm & $2-5 \mathrm{sec}$ \\
\hline $\mathbf{7 .}$ & J ring Flow Diameter & $550-850 \mathrm{~mm}$ \\
\hline
\end{tabular}

\section{SLUMP FLOW TEST AND T50cm TEST}

This test is the most common test used to assess the horizontal free flow of SCC in the absence of obstructions. This test is easy to carry out and can provide an indication of flowability. On lifting the slump cone, filled with concrete, the concrete flows. The average diameter of the concrete circle is a measure for the filling ability of the concrete. The time $\mathrm{T} 50 \mathrm{~cm}$ is a secondary indication of flow. It measures the time taken in seconds from the instant the cone is lifted to the instant when horizontal flow reaches diameter of $500 \mathrm{~mm}$. as shown in (fig.1).

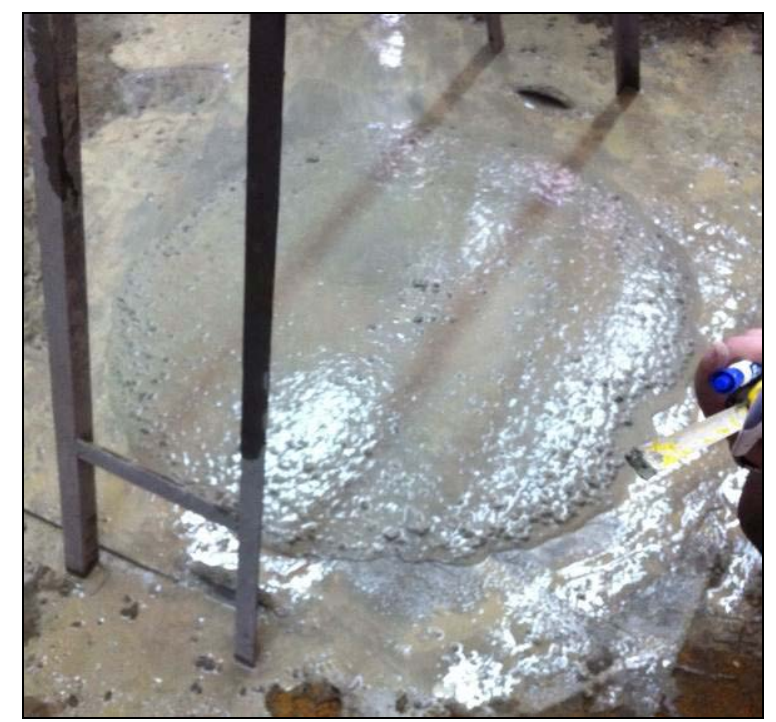

Fig.1. Rheological properties of SCC using slump flow test

\section{V-FUNNEL TEST AT (T0sec) AND (T5min)}

This test consists of a V-shaped funnel, as shown in (fig.2). This test is used to determine the flowability of fresh concrete, whereby the flow time is measured. The funnel is filled with about 12 liter of concrete and the time taken for it to flow through the apparatus is measured. Further, T $5 \mathrm{~min}$ is also measured with V-funnel, which indicates the tendency for segregation, where in the funnel can be refilled with concrete and left for 5 minutes to settle. 


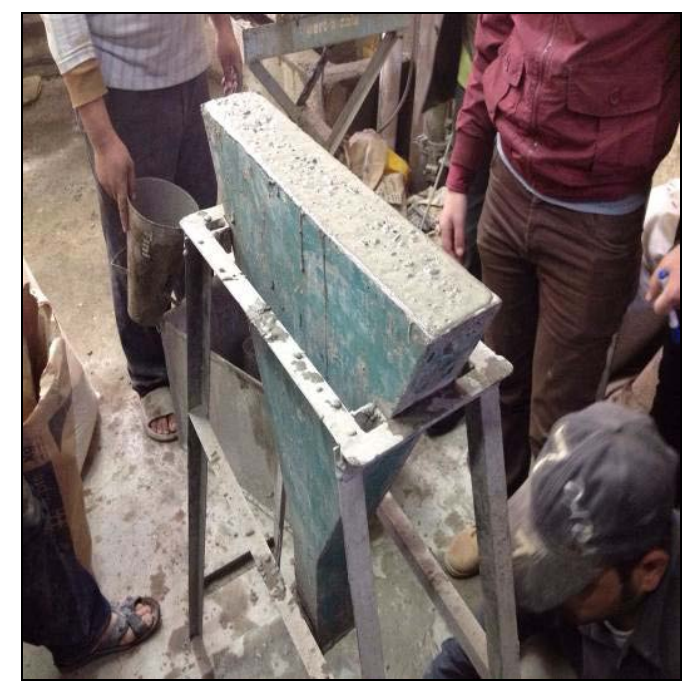

Fig.2. Rheological properties of SCC using V-funnel test

\section{J-RING TEST}

This test used to determine the passing ability and the flowability of concrete. The equipment of this test shown in (fig.3). The slump cone is filled with concrete as in the slump flow test. Measure the difference in the height between the concrete just inside the bars and outside the bars. Also $750 \mathrm{~cm}$ and final spread diameter in two orthogonal directions are measured.

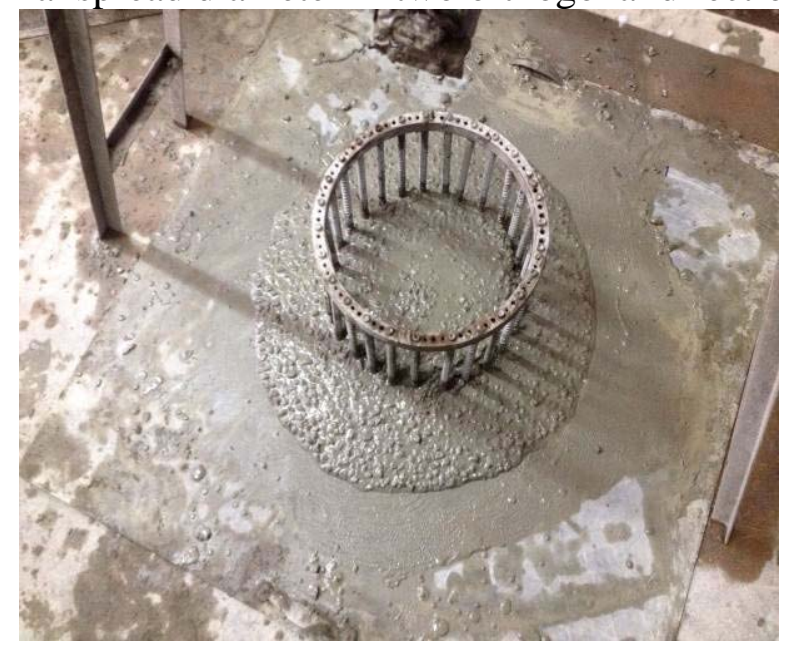

Fig.3. Rheological properties of SCC using J-ring test

\section{4- EXPERIMENTAL PROCEDURE}

Using absolute volume method for design of SCC mixes.

\section{Absolute volume $=$ Wc $/$ Gc + Ws $/$ Gs + Wd / Gd+Wf.a / Gf.a + Ws.f / Gs.f $+\mathrm{Wvc} / \mathrm{Gvc}+\mathrm{Ww} / \mathrm{Gw}=1000$ liter $=1 \mathrm{~m}^{3}$}

$\mathbf{W c}=$ weight of cement required for $1 \mathrm{~m} 3$ of concrete.

Ws $=$ weight of sand required for $1 \mathrm{~m} 3$ of concrete.

$\mathbf{W g}=$ weight of dolomite required for $1 \mathrm{~m} 3$ of concrete.

Wf.a = weight of fly ash required for $1 \mathrm{~m} 3$ of concrete.

Ws.f $=$ weight of silica fume required for $1 \mathrm{~m} 3$ of concrete.

$\mathbf{W v c}=$ weight of viscocrete required for $1 \mathrm{~m} 3$ of concrete.

$\mathbf{W w}=$ weight of water required for $1 \mathrm{~m} 3$ of concrete.

Gc, Gs, Gd, Gf.a, Gs.f, Gvc, Gw = specific weight of cement, sand, dolomite, fly ash, silica fume, viscocrete and water in series. As shown in (table 3). 
Table (3) Physical Material Properties of SCC Constitutes

\begin{tabular}{|l|c|}
\hline \multicolumn{1}{|c|}{ Material } & Specific Gravity \\
\hline Cement & 3.15 \\
\hline Additive - silica fume & 2.1 \\
\hline Additive -Fly ash & 2.3 \\
\hline water & 1 \\
\hline Coarse aggregate (Dolomite) & 2.5 \\
\hline Fine aggregate (Sand) & 2.65 \\
\hline
\end{tabular}

Eighteen self compacted concrete mixes with different water/binder ratio from many researches as shown in (table 4). And redesign it by using absolute volume design method to check in its components by using local available materials. Materials content range may vary based on replacement of silica fume and fly ash at different levels. Study the effect of mineral admixtures -fly ash and silica fume - on rheological and hardened properties of SCC. The test results for acceptance characteristics of self-compacting concrete such as slump flow, J-ring and V-funnel are presented. Further, compressive strength at the ages of 7 and 28 days was also determined and results are analyzed and discussed.

Table (4) Self Compacting Concrete Constitutes For Different Mixes

\begin{tabular}{|c|c|c|c|c|c|c|c|c|}
\hline Mix no. & $\begin{array}{l}\text { Cement( } \\
\text { Kg/m3) }\end{array}$ & $\begin{array}{l}\text { C.A } \\
(\mathrm{Kg} / \mathrm{m} 3)\end{array}$ & $\begin{array}{l}\text { F.A } \\
(\mathrm{Kg} / \mathrm{m} 3)\end{array}$ & $\begin{array}{l}\text { Fly ash } \\
(\mathrm{Kg} / \mathrm{m} 3)\end{array}$ & $\begin{array}{c}\text { Viscocrete } \\
\text { (lit/m3) }\end{array}$ & $\begin{array}{l}\text { Silica fume } \\
(\mathrm{Kg} / \mathrm{m} 3)\end{array}$ & $\begin{array}{l}\text { Water } \\
(\mathrm{Kg} / \mathrm{m} 3)\end{array}$ & $\begin{array}{c}\text { w/b } \\
\text { ratio }\end{array}$ \\
\hline M1[7] & 324.68 & 771.8 & 836 & 149.85 & 4.5 & 25 & 179.82 & 0.36 \\
\hline M2[7] & 536 & 771.8 & 836 & 0 & 4.824 & 0 & 192.96 & 0.36 \\
\hline M3[11] & 425 & 686 & 838 & 85 & 8.5 & 0 & 148.75 & 0.29 \\
\hline M4[7] & 485 & 561 & 977 & 135 & 7.068 & 0 & 256 & 0.41 \\
\hline M5 & 145 & 705 & 989 & 204.4 & 6.118 & 87.6 & 176.92 & 0.40 \\
\hline M6[7] & 355.25 & 771.8 & 836 & 101.5 & 4.57 & 50.75 & 182.7 & 0.36 \\
\hline M7[7] & 378 & 771.8 & 836 & 50.4 & 4.53 & 76.6 & 181.44 & 0.36 \\
\hline M8[11] & 425 & 686 & 838 & 85 & 8.5 & 21.25 & 148.75 & 0.28 \\
\hline M9[2] & 485 & 561 & 977 & 135 & 7.068 & 0 & 254 & 0.41 \\
\hline M10[2] & 485 & 561 & 977 & 135 & 7.068 & 0 & 253 & 0.41 \\
\hline M11[3] & 384 & 589 & 902 & 205 & 12 & 0 & 191 & 0.32 \\
\hline M12[3] & 350 & 566 & 868 & 236 & 15.4 & 0 & 193 & 0.33 \\
\hline M13[3] & 348 & 582 & 886 & 269 & 11.7 & 0 & 191 & 0.31 \\
\hline M14[3] & 351 & 473 & 875 & 271 & 9 & 0 & 192 & 0.31 \\
\hline M15[4] & 239 & 958 & 722 & 204 & 3 & 0 & 198 & 0.45 \\
\hline M16[4] & 309 & 950 & 727 & 206 & 6 & 0 & 167 & 0.32 \\
\hline M17[4] & 420 & 778 & 750 & 185 & 16 & 67.2 & 166 & 0.24 \\
\hline M18[10] & 450 & 630 & 630 & 330 & 13.5 & 40 & 180 & 0.22 \\
\hline
\end{tabular}

\section{5- RESULTS AND DISCUSSION}

Table (5) presents the results of rheological tests, conducted to achieve self-compacting concrete. The consistency and workability of M1toM3,M7,M8and from M15to M18 satisfied slump flow property and also all this mixes have the V-funnel time T0 between 6-12 sec and $\mathrm{V}$-funnel time $\mathrm{T} 5 \mathrm{~min}$ within the range of $\mathrm{T} 0+3$. The J-ring difference $\Delta \mathrm{H}$ also satisfied for this mixes in arrange between (0 to 20mm). None of the SCC characteristics was found in the mixes from M4 to M6 and from M9 to M14. Figure (4) comparison between 
diameters of flow for slump flow test and J ring test. Figure (5) shows Relations between T0 and $\mathrm{T} 5 \mathrm{~min}$ for $\mathrm{V}$ funnel test.

Table (5) Results of Rheological Properties of SCC Mix Containing Different Percentages of Silica Fume or Fly Ash

\begin{tabular}{|c|c|c|c|c|c|c|c|c|c|}
\hline TEST & \multicolumn{3}{|c|}{ Slump flow test } & \multicolumn{2}{|c|}{ V-funnel test } & \multicolumn{4}{|c|}{$\mathrm{J}$-ring test } \\
\hline $\begin{array}{c}\text { Mix } \\
\text { Code. }\end{array}$ & \multicolumn{2}{|c|}{$\begin{array}{l}\text { Diameter of flow } \\
(60-80) \mathrm{cm}\end{array}$} & \multirow{2}{*}{$\begin{array}{c}\begin{array}{c}\text { T50 sec } \\
(2-5)\end{array} \\
3.46\end{array}$} & \multirow{2}{*}{$\begin{array}{c}\text { T0 (sec) } \\
(\mathbf{6}-\mathbf{1 2})\end{array}$} & \multirow{2}{*}{$\begin{array}{c}\text { T } 5 \min (\mathbf{6}- \\
\mathbf{1 5}) \\
7.5\end{array}$} & \multirow{2}{*}{$\begin{array}{r}\Delta \mathbf{H} \\
1.9\end{array}$} & \multirow{2}{*}{$\begin{array}{c}\mathbf{T 5 0} \\
2.7\end{array}$} & \multicolumn{2}{|c|}{$\begin{array}{c}\text { Flow diameter } \\
(60-80) \mathrm{cm}\end{array}$} \\
\hline M1 & 60 & 62 & & & & & & 55 & 56 \\
\hline M2 & 70 & 70 & 3.03 & 7.2 & 9.2 & 1.8 & 6.13 & 63 & 61 \\
\hline M3 & 60 & 60 & 5 & 13 & 15 & 2 & 8 & 52 & 54 \\
\hline M4 & 83 & 90 & 1 & 1.92 & 2.5 & 0 & 3.7 & 80 & 80 \\
\hline M5 & 50 & 50 & 3.1 & 4 & 7.6 & 1 & - & 36 & 36 \\
\hline M6 & 52 & 50 & 5.8 & 4.27 & 6.6 & 1.3 & 6.43 & 44 & 44 \\
\hline M7 & 66 & 65 & 2 & 6.7 & 8.6 & 0.5 & 2.48 & 60 & 63 \\
\hline M8 & 64 & 67 & 4.65 & 7.06 & 8.11 & 1.5 & 8.2 & 53 & 57 \\
\hline M9 & \multicolumn{9}{|c|}{ Failed } \\
\hline M10 & \multicolumn{9}{|c|}{ Failed } \\
\hline M11 & 92 & 92 & 2.25 & 3 & 5 & 0.2 & 4.33 & 75 & 80 \\
\hline M12 & \multicolumn{9}{|c|}{ Failed } \\
\hline M13 & 88 & 88 & 1.62 & 4.77 & 6.52 & 0.1 & 4 & 83 & 81 \\
\hline M14 & 94 & 94 & 2.4 & 5.8 & 5.92 & 0 & 4.07 & 85 & 84 \\
\hline M15 & 80 & 75 & 2.1 & 7.7 & 9.7 & 0.4 & 3.8 & 65 & 67 \\
\hline M16 & 79 & 79 & 2.1 & 6.3 & 8.91 & 2 & 14.6 & 65 & 65 \\
\hline M17 & 78 & 74 & 2.39 & 6.42 & 7.94 & 1.8 & 6.92 & 65 & 65 \\
\hline M18 & 80 & 81 & 2 & 6.41 & 6.92 & 0 & 5.41 & 71 & 72 \\
\hline
\end{tabular}

\section{Where}

T50 cm: time for concrete diameter to reach $500 \mathrm{~mm}$.

T0 min: V-funnel flow time after keeping the concrete in the funnel for $10 \mathrm{sec}$

T5 min: V-funnel flow time after keeping the concrete in the funnel for 5 min

$\Delta \mathrm{H}$ : difference in height between the concrete just inside the bars and outside the bars. 


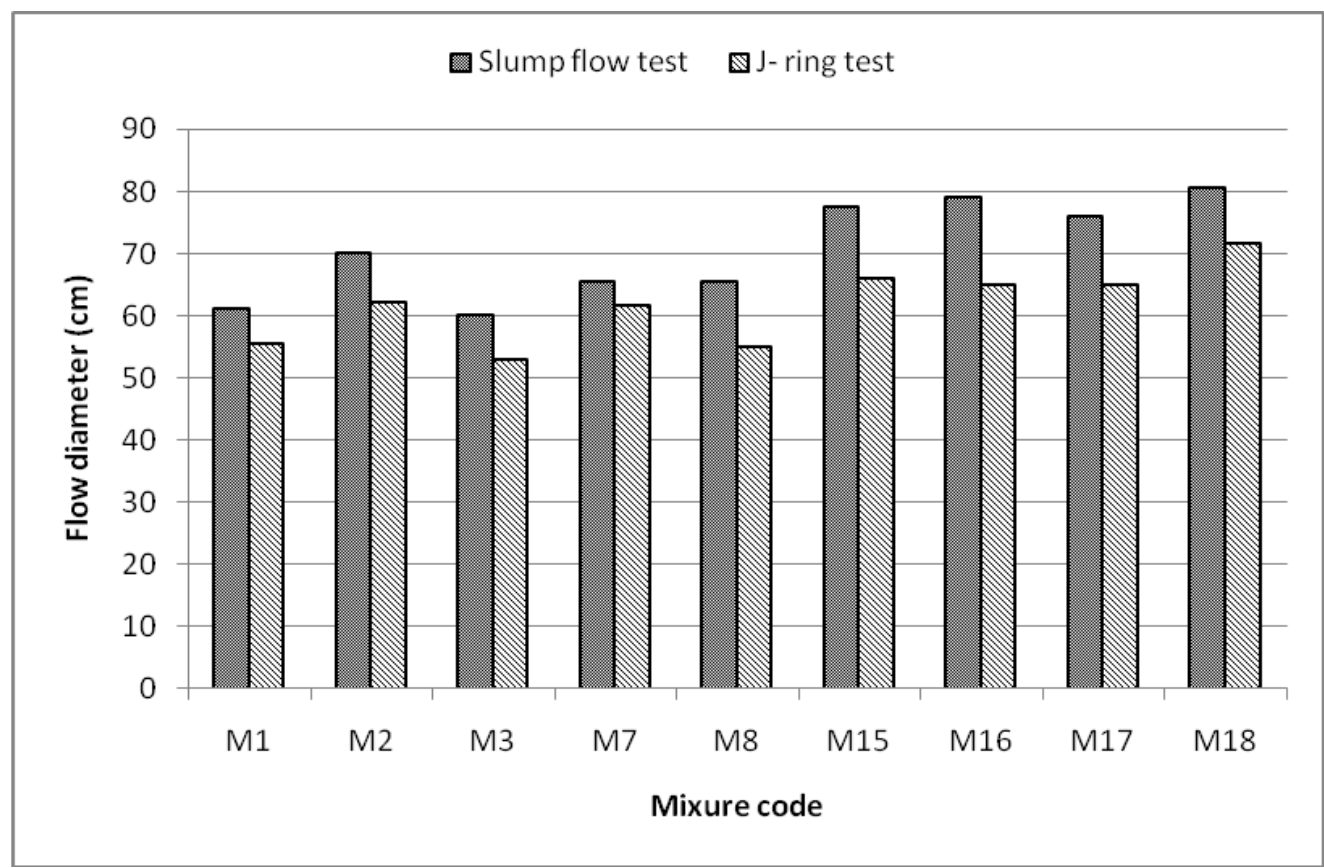

Figure (4) comparison between flow diameters

For slump flow test and J-ring test

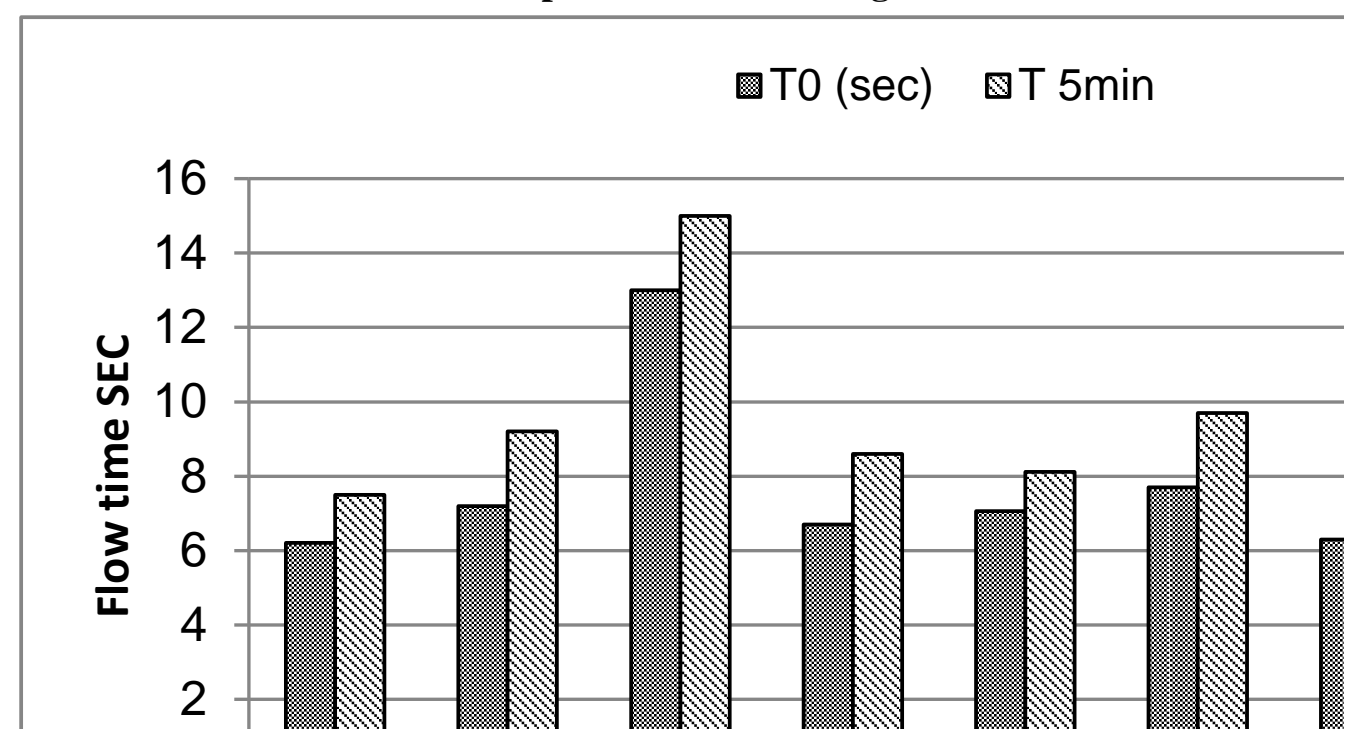

Figure (5) Relations between T0 and T5 min for V-funnel test

\section{6- Mechanical Properties of Hardened SCC}

Cubes with $15 \mathrm{~cm}$ side length were used for determining of SCC compressive strength (Fcu) the concrete was placed in a steel molds without any compacting or vibrator and then their surfaces were finished using towel.Table.6. Show the physical and mechanical properties of SCC mix.(unit weight and compressive stresses after 7 and 28 days). Figure 6 showing the Comparison between compressive strength for different SCC mixes. Figure 7 showing the Comparison test and modes of failure for different SCC mixes. 


\begin{tabular}{|c|c|c|c|}
\hline MIX NO. & unit weight ton/m3 & $\begin{array}{c}\text { Stresses (Mpa) } \\
\text { after 7 days }\end{array}$ & $\begin{array}{c}\text { Stresses (Mpa) } \\
\text { after 28 days }\end{array}$ \\
\hline M1 & 2.20 & 19 & 30.7 \\
\hline M2 & 2.32 & 37.55 & 49.4 \\
\hline M3 & 2.31 & 34.185 & 51.67 \\
\hline M7 & 2.31 & 32.1 & 49.95 \\
\hline M8 & 2.34 & 41.2 & 58.25 \\
\hline M15 & 2.36 & 22 & 33 \\
\hline M16 & 2.39 & 34.45 & 42 \\
\hline M17 & 2.36 & 45.25 & 70.3 \\
\hline M18 & 2.36 & 40.2 & 58.4 \\
\hline
\end{tabular}

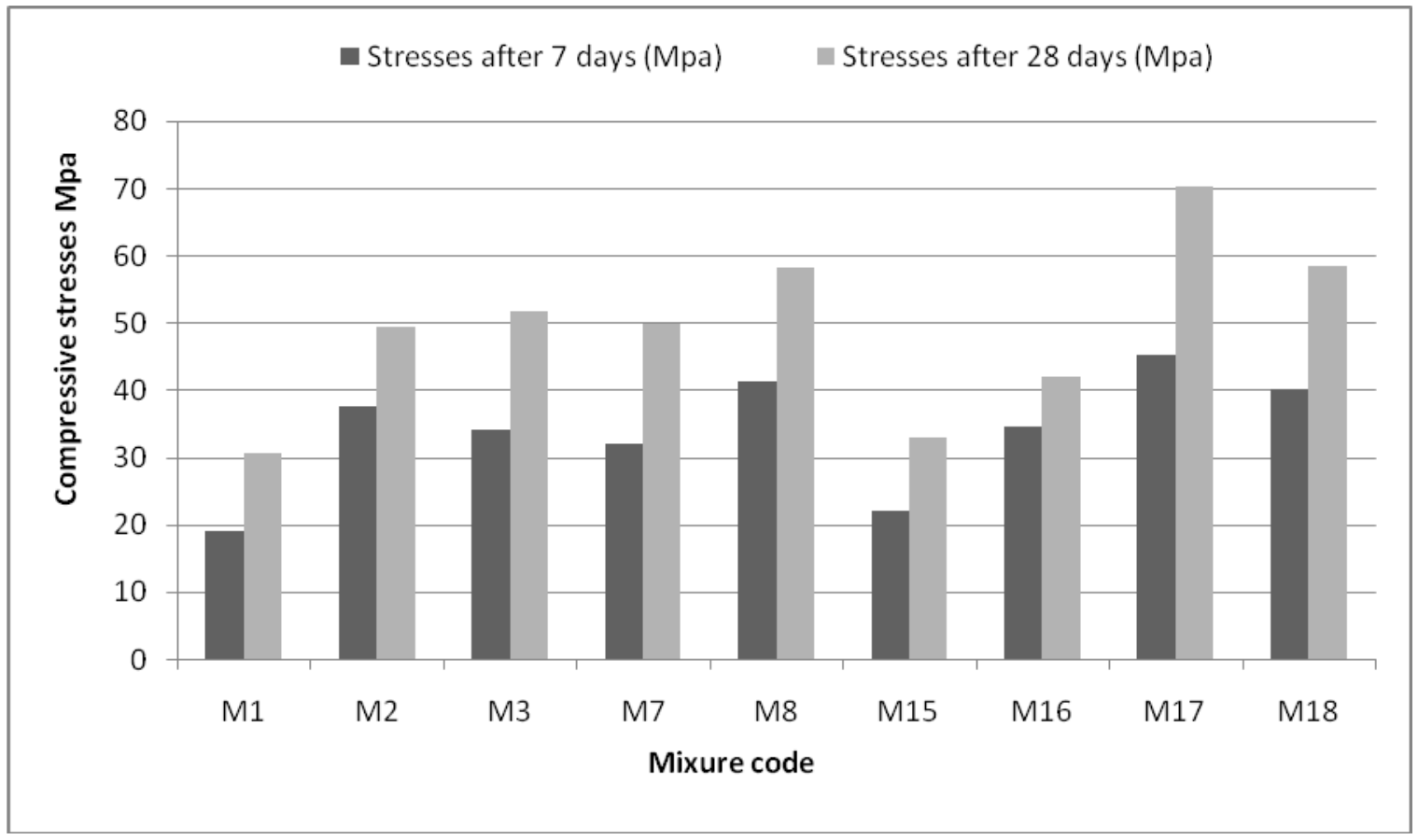

Figure 6: Comparison between compressive strength for different SCC mixes 

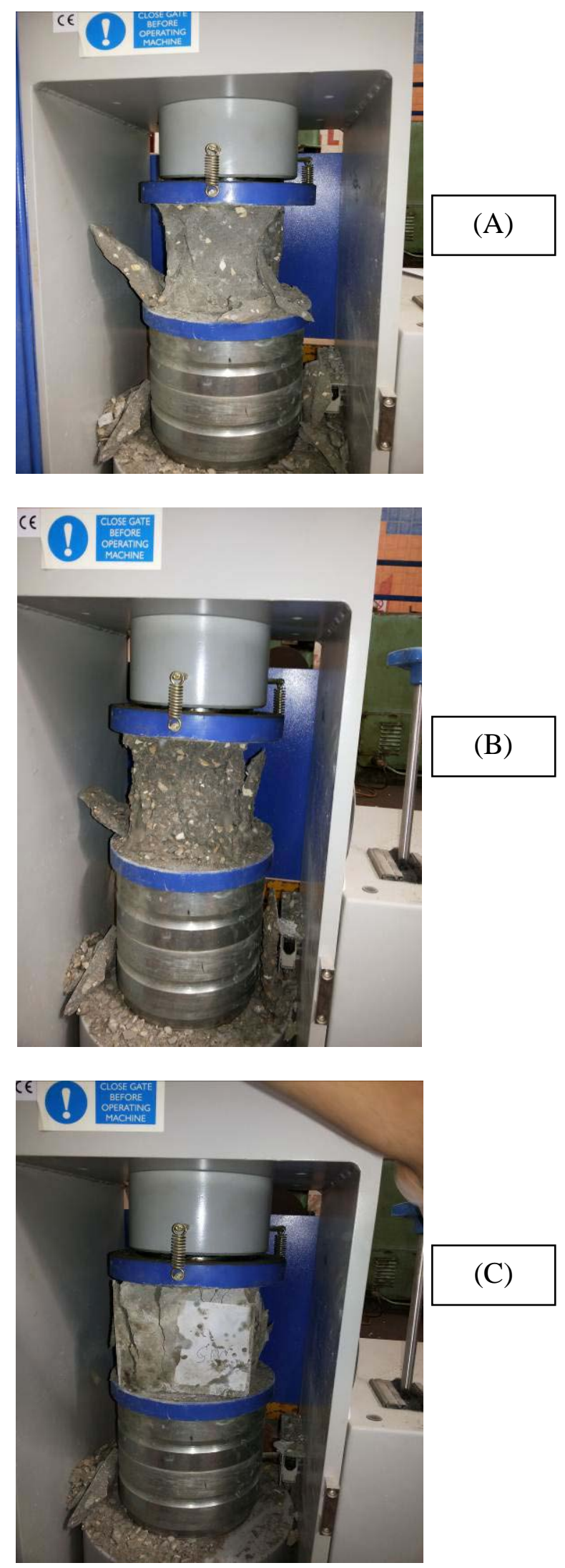

Figure 7: Compression test and modes of failure for different SCC mixes 


\section{CONCLUSIONS:}

1- For site quality, tests methods are generally sufficient to monitor production quality such as slump flow test, $\mathrm{V}$-funnel test, and J-ring test.

2- The homogeneity of self-compacted concrete(SCC) depends on combinations of several factors, including types of aggregates, water content, cement content, dosage of viscosity enhancing admixture(viscocrete) and types of filler (fly ash or silica fume)

3- self-compacted concrete(SCC) can be produced with locally available materials.

4- Silica fume increases the strength of SCC more than fly ash but it needs a high dosage of viscocrete as shown in mix no. (M17,M18).

5- Viscocrete is an essential need to prevent segregation of self- compacted concrete mixes.

6- Self-compacted concrete could be developed without using mineral admixtures (fly ash or silica fume) as in mix no.(M2).

7- Using high percentage of viscocrete getting high compressive strength as shown in mix no. (M17). 


\section{REFERENCES:}

[1] Frances Yang, “self - consolidating concrete”, CE 214: concrete technology, spring 2004: Report \# 1.

[2] Aggarwal, P., Siddique, R., Aggarwal, Y., and Mgupta, S., "Self-Compacting concreteprocedure for mix design", Leonardo Electronic Journal of Practices and Technologies, Issue 12, January, pp. 15-24. 2008.

[3] Selçuk Türkel and Ali Kandemir, "Fresh and Hardened Properties of SCC Made with Different Aggregate and Mineral Admixtures”, Journal of Materials in Civil Engineering, Vol. 22, No. 10, October 1, 2010. ASCE, ISSN 0899-1561.

[4] T. Yu, X.L. Fang and J.G.Teng , "FRP-Confined Self-Compacting Concrete under Axial Compression”, Journal of Materials in Civil Engineering, 04014082-1:04014082-8. 2014.

[5] Felekoglu, B., Turkel, S., and Baradan, B., “ Effect of water/cement ratio on the fresh and hardened properties of self-compacting concrete”, Building and Environment,Vol. 42, pp. 1795-1802. 2007.

[6]Paratibha AGGARWAL, Rafat SIDDIQUE, Yogesh AGGARWAL, Surinder M GUPTA, “Self-Compacting Concrete - Procedure for Mix Design”, Leonardo Electronic Journal of Practices and Technologies, Issue 12, January, p. 15-24, India, 2008.

[7]Krishna Murthy.N, Narasimha Rao A.V, Ramana Reddy I .Vand Vijaya sekhar Reddy.M,"Mix Design Procedure for Self Compacting Concrete", Journal of Engineering (IOSRJEN), Volume 2, Issue 9 ,September, PP 33-41, India ,2012.

[8] ESS 4756-1 "Composition, Requirements and Compliance Criteria for Common Cement”, Egyptian Organization for Standardization, Egypt, 2005.

[9]ETS-2009, “Egyptian Technical Specifications for Self Compacting Concrete”, Housing and Building National Research Center, Egypt, 2009.

[10]Mahmoud Ramzy"Ductility \& Moment Redistribution in Self-Compacting Lightweight R.C. Continuous Beams", M.Sc. thesis, ain shams university,2011.

[11] zeinab amen ,"properties and fields of application of self compacted concrete ", M.Sc. thesis, menofia university,2004.

[12] A. Kh. EL-Baz, M.Sc. Ain shams university, "Behavior and Analysis of FRP Externally Confined Self Compacted Concrete Columns under Eccentric Loading ", Under Publishing.

[13] A. Kh. EL-Baz, Heiza, Arafat, El-Nabawy. "State of the art report on self-compacting concrete filled FRP tubes", ${ }^{1} \mathrm{st}$ international conference on innovative building material, HBRC, Egypt, 28-30 December 2014. 